\title{
Sp1 and KLF15 regulate basal transcription of the human LRP5 gene
}

\author{
Jiangxia Li, Yang Yang, Baichun Jiang, Xiyu Zhang, Yongxin Zou, Yaoqin Gong*
}

\begin{abstract}
Background: LRP5, a member of the low density lipoprotein receptor superfamily, regulates diverse developmental processes in embryogenesis and maintains physiological homeostasis in adult organisms. However, how the expression of human LRP5 gene is regulated remains unclear.

Results: In order to characterize the transcriptional regulation of human $\angle R P 5$ gene, we cloned the $5^{\prime}$ flanking region and evaluated its transcriptional activity in a luciferase reporter system. We demonstrated that both KLF15 and Sp1 binding sites between -72 bp and -53 bp contribute to the transcriptional activation of human LRP5 promoter. Chromatin immunoprecipitation assay demonstrated that the ubiquitous transcription factors KLF15 and Sp1 bind to this region. Using Drosophila SL2 cells, we showed that KLF15 and Sp1 trans-activated the LRP5 promoter in a manner dependent on the presence of Sp1-binding and KLF15-binding motifs.
\end{abstract}

Conclusions: Both KLF15 and Sp1 binding sites contribute to the basal activity of human LRP5 promoter. This study provides the first insight into the mechanisms by which transcription of human LRP5 gene is regulated.

\section{Background}

The LRP5 gene, located on human chromosome 11q13, contains 23 exons encoding a 1615 amino acid singlepass transmembrane receptor that belongs to the low density lipoprotein (LDL) receptor superfamily. LRP5 is highly conserved between species. There is $95 \%$ identity between human and mouse LRP5 protein[1], and 40\% identity with the Drosophila orthologous gene, Arrow [2]. Additionally, LRP5 bears $71 \%$ amino acid identity with LRP6[3]. LRP5 contains an extracellular domain, a membrane-spanning domain, and an intracellular domain. The extracellular domain, located at the N-terminus, consists of four EGF-receptor-like cysteine-rich repeats with associated YWTD spacer domains and three LDL receptor-like ligand binding domains[1]. LRP5 is expressed in multiple adult and embryonic tissues, including bone, macrophages, fat, brain, heart, liver, skin and pancreas, with strongest expression occurring in the liver[1]. In bone, it is expressed by osteoblasts of the endosteal and trabecular bone surfaces but not by osteoclasts[4,5].

\footnotetext{
* Correspondence: yxg8@sdu.edu.cn
Key Laboratory for Experimental Teratology of the Ministry of Education and

* Correspondence: yxg8@sdu.edu.cn
Key Laboratory for Experimental Teratology of the Ministry of Education and Institute of Medical Genetics, Shandong University School of Medicine, Jinan, Shandong, China
}

(c) $2010 \mathrm{Li}$ et al; licensee BioMed Central Ltd. This is an Open Access article distributed under the terms of the Creative Commons Attribution License (http://creativecommons.org/licenses/by/2.0), which permits unrestricted use, distribution, and reproduction in any medium, provided the original work is properly cited.

Shortly after the discovery of LRP5, multiple lines of evidence indicate that the LRP5 plays an important role in bone formation through the Wnt signaling pathway $[4,6,7]$. Loss-of-function mutations in human LRP5 gene cause the osteoporosis-pseudoglioma syndrome (OPPG), an autosomal-recessive condition of juvenile onset characterized by blindness due to aberrant vitreo-retinal vascular growth and osteoporosis resulting in fractures and deformation[4]. Gain-of-function mutation (G171V) in the same gene, on the other hand, resulted in high bone mass (HBM) [6-8]. Consistent with the observations in human, bone formation and osteoblast proliferation are decreased in Lrp5-deficient mice[5], and transgenic mice that expressed the LRP5 G171V mutation in osteoblasts exhibited enhanced osteoblastic activity, reduced osteoblast apoptosis, and a high bone mass phenotype [9]. Furthermore, independent epidemiological studies have linked sequence variants in LRP5 gene with differences in bone mineral density (BMD) and/or fracture risk [10-13].

Consistent with the observation with the OPPG patients, other diseases associated with abnormal angiogenesis or vascularization of the eye are also associated with mutations in LRPS or its paralog LRP6 as well as proteins that interact with the two receptors, including familial 
exudative vitroretinopathy [14-16], Norrie disease[17], and macular degeneration [18]. In addition to its essential role in bone accrual and eye development, the LRP5 is also required for normal cholesterol and glucose metabolism $[19,20]$. Thus, LRP5 is a widely expressed receptor and is critical for normal development. It regulates diverse developmental processes in embryogenesis and maintains physiological homeostasis in adult organisms. Interestingly, the most studied functions of LRP5 are related to its roles as a co-receptor for the frizzled family of Wnt receptors. Yadav et al recently demonstrated the existence of a novel regulatory pathway whereby gut-derived 5-hydroxytryptamine indirectly mediates the function of LRP5 in skeletal differentiation [21].

Despite its important roles in several developmental processes, the transcriptional regulation of LRP5 remains unclear. Information regarding the regulation of LRP5 gene expression may help us to understand its function and find potential new anabolic targets for conditions such as osteoporosis. To this end, we cloned the 5 ' flanking region and evaluated its transcriptional activity in a luciferase reporter system. We demonstrate that both Krüppel-like factor 15(KLF15) and specificity protein 1(Sp1) binding motifs are essential for human LRP5 promoter activity.

\section{Results}

Identification of putative transcription factor binding sites in human $L R P 5$ promoter region

Before characterizing human LRP5 promoter, primer extension was performed to identify the transcription start site (TSS) of human LRP5 gene. We observed that the TSS of human LRP5 gene was located 40 nucleotides upstream of the $5^{\prime}$ end of the published cDNA sequence (GenBank accession No: NM_002335), corresponding to a $\mathrm{T}$ residue at position 114 upstream of the ATG translation start site (Figure. 1A). In order to identify putative transcription factor binding sites, we analyzed the human LRP5 5'-flanking sequence from -2381 to +125 (relative to transcription start site) using the programs MatInspector http://www.genomatix.de/products/MatInspector/ and AliBaba $2.1 \mathrm{http}: / / \mathrm{www} . g e n e-$ regulation.com/pub/programs.html. No canonical TATA box or CAAT-like sequences were evident. However, several potential transcription factor binding motifs were identified in the promoter region close to transcription start site, including Sp1, KLF15, MZF, MAZ, CDE and ZBPF (Figure. 1B).

The minimal promoter of human LRP5 gene is located within the region $-72 /-53$ relative to the transcription start site

To determine the minimal region required for basal activity of the LRP5 promoter, a series of deletion constructs were generated, designated as pWT-2381, pWT-1901, pWT-1594, pWT-1442, pWT-1309, pWT1167, pWT-1085, pWT-953 and pWT-359 based on their variable 5' end. U2OS and HEK293 cells, representing cells of osteoblastic and non-osteoblastic origin, respectively, were used to evaluate the promoter activities and to determine whether there exist regulatory elements that are specific to osteoblastic cells. Figure $2 \mathrm{~A}$ summarizes the results of these transfection analyses. Maximal promoter activity was observed with the construct pWT-359 in both U2OS and HEK293 cells. When the sequence length increased up to -2381 , a $50 \%$ reduction in luciferase activities was observed, suggesting the presence of negative regulatory elements between -2381 and -359 . These results indicate that the human LRP5 proximal promoter elements are located downstream -359 and that there are essential positive control elements within the sequence from -359 to +125 . Similar trends were observed in U2OS cells and HEK293 cells, suggesting that the regulatory sequences within the region examined were not cell-specific.

To further define the sequence required for proximal LRP5 promoter activity, a new series of deletion constructs were then generated by PCR, designed as PWT219, pWT-167, pWT-72, pWT-53 and pWT-40. The relative luciferase activities were compared to that of pWT-359 construct which was set as $100 \%$. As shown in figure $2 \mathrm{~B}$, no significant reduction of the reporter activity was detected in the HEK293 and U2OS cell lines when deletions were made between -359 and -72 . However, deletion from nucleotides -72 to -53 resulted in $80 \%$ reduction in the promoter activity. These deletion experiments indicate that the essential positive control elements for LRP5 promoter activity are located between -72 and -53 . Therefore, we decided to firstly focus our interest on the minimal promoter of human LRP5 gene.

The KLF15 and Sp1 binding sites between -72 and -53 contribute to human LRP5 promoter activity

The region between -72 and -53 is a GC-rich region, containing two overlapped transcription factor binding sites, one for KLF15 and the other for Sp1. To determine the contribution of the Sp1 and/or KLF15 sites to the promoter activity, point mutations were introduced into construct pWT-72 by PCR-based mutagenesis to generate either single or double mutant reporter plasmids which were designated as pMT1-72, pMT2-72, and pMT12-72, respectively (Figure. 3A). In pMT1-72, the KLF15 motif GCGGGGGG was mutated to GCTTTGGG, and in pMT2-72 the Sp1 motif GGGCGGA was mutated to GGGTTGA. The double mutant construct pMT12-72 contained mutations in both motifs. The luciferase activities driven by the native 


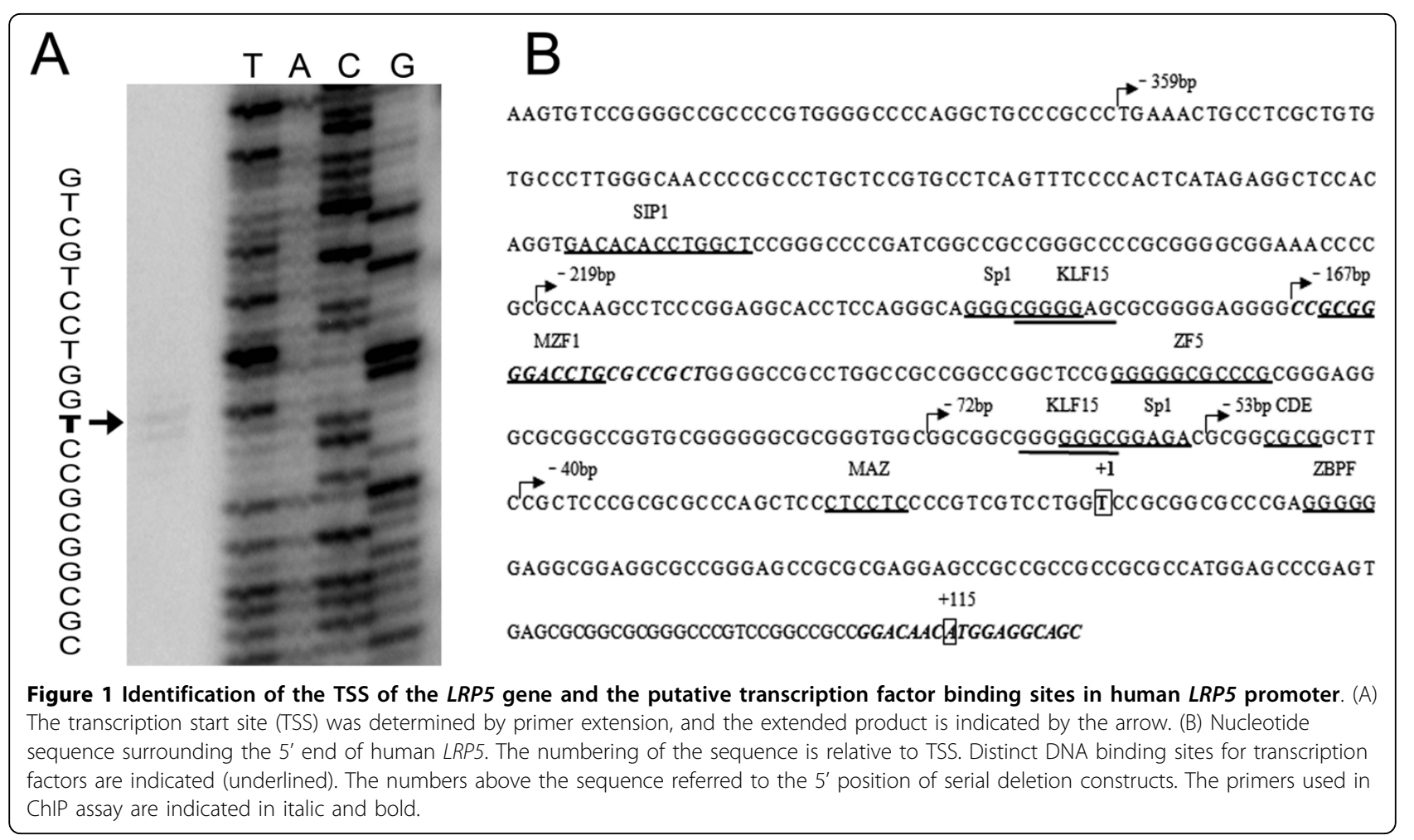

(pWT-72) and mutated constructs were measured in HEK293 and U2OS cells. As illustrated in figure 3B, relative to pWT-72, pMT1-72 and pMT2-72 showed $22-25 \%$ and $53-55 \%$ reduction in promoter activity, respectively, confirming the positive regulatory role of the KLF15 site and the Sp1 site. The luciferase activity driven by double mutant (pMT12-72) was reduced to $11 \%$ in HEK 293 and $20 \%$ in U2OS cells, the values as observed in the construct that lacks both KLF15 and Sp1 binding sites (pWT-53). These results indicate that both KLF15 and Sp1 binding sites between -72 and -53 of human LRP5 promoter contribute to the basal activity of human LRP5 transcription.

\section{Trans-activation of human LRP5 promoter by KLF15 and Sp1}

To determine whether KLF15 and Sp1 functionally modulate the LRP5 promoter activity, Drosophila SL2 cells, which are deficient in Sp1 and KLF15, were utilized. SL2 cells were cotransfected with either the wild type pWT-72 construct or the constructs with mutated Sp1 and/or KLF15 binding sites along with the KLF15 or Sp1 expression plasmids. As shown in figure $3 \mathrm{C}$ and 3D, Sp1 and KLF15 stimulated LRP5 promoter activity of the wild type construct. However, the mutant constructs were not activated by co-transfection with corresponding expression constructs, pPacSp1 (Figure 3C) or pPacKLF15 (Figure 3D), indicating that transactivation of the LRP5 by Sp1 and KLF15 depends on the presence of Sp1-binding and KLF15-binding motifs in the LRP5 promoter.

\section{In vivo binding of Sp1 and KLF15 to human LRP5 promoter}

To verify in vivo promoter binding by transcription factors KLF15 and Sp1, chromatin immunoprecipitation (ChIP) was performed on HEK293 cells. The sonicated nuclear extract was subjected to immunoprecipitation with anti-KLF15 and anti-Sp1 antibodies, and the associated chromatin DNA fragments were amplified with the primer pairs flanking the KLF15 and Sp1 binding sites as shown in figure $1 \mathrm{~B}$. As a negative control, a reaction was included with antibodies against IgG. The HSD17B5 promoter which contains both $\mathrm{Sp} 1$ and KLF15 binding sites was used as a positive control [22]. As shown in figure 3E, Anti-KLF15 and anit-Sp1 antibodies, but not IgG antibodies, could immunoprecipitate the HSD17B5 promoter and LRP5 promoter in HEK293 cells. These results confirm that human LRP5 promoter is indeed bound by Sp1 and KLF15 transcription factors in vivo.

\section{Discussion}

In the present study, we have for the first time cloned the human LRP5 promoter and analyzed its transcriptional regulation. We demonstrated that both KLF15 


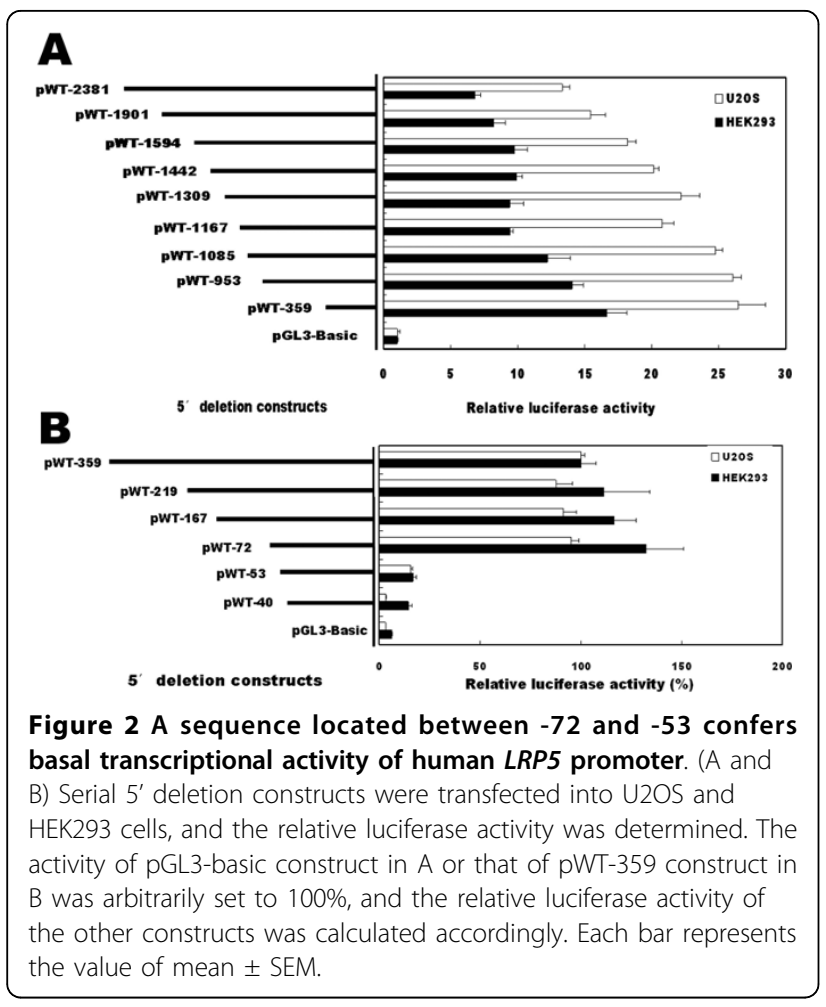

and Sp1 binding sites located between -72 and -53 contribute to basal promoter activity of human LRP5 gene. There are several lines of evidences. First, by generating a series of $5^{\prime}$ deletions, we show that the core promoter is located between nucleotides -72 and -53 relative to transcription start site. Second, changing the KLF15 and Sp1 motifs within this region by introducing point mutations strongly reduced LRP5 promoter activity. Third, in Drosophila SL2 cells that lack endogenous Sp1 and KLF15, we show that expression of KLF15 and Sp1 is able to trans-activate the $L R P 5$ promoter that contains Sp1-binding and KLF15-binding motifs. Finally, ChIP assay confirmed the binding of KLF15 and Sp1 to the LRP5 promoter in vivo.

Kruppel-like factors (KLFs), a subclass of the zinc-finger family of transcriptional regulators, are critical regulators of growth and differentiation in a broad range of mammalian cell types[23,24]. Members of this gene family have been characterized as regulators of both tissue-specific and ubiquitous genes and can function as transcriptional activators and/or repressors depending on promoter context[24,25]. KLF15 is expressed in multiple tissues, including liver, white and brown adipose tissues, kidney, heart, and skeletal muscle, with strongest expression occurring in the liver and kidney[26]. KLF15 appears to be bi-functional, as it represses the Rho and IRBP promoters [27] and the kidney-specific CLC-K1 and $C L C-K 2$ promoters [28], but activates the GLUT4 promoter[26] and AceCs 2 promoter[29]. In this study, mutation of the KLF15 binding motif lead to a reduction of the promoter activity in HEK293 and U2OS cells, indicating that this motif located between -72 and -53 functions as a positive regulatory element and activates the human LRP5 promoter.

The zinc-finger protein $\mathrm{Sp}$, which belongs to $\mathrm{Sp}$ family, was identified as the major protein forming complexes with oligonucleotides containing Sp1 and KLF15 binding motifs. The Sp family has 9 members containing three conserved zinc finger DNA binding domains, designated Sp1 to Sp9. Among them, Sp1, Sp3 and Sp4 are closely related containing two major glutamine-rich transactivation domains that are essential for transcription activation. They bind GC motifs to regulate the expression of housekeeping, tissue-specific and viral genes[30,31]. In the present study, we identified a functional Sp1 binding site within the core promoter of human LRP5 gene. Mutation of the Sp1 site decreased the promoter activity by $53 \%$ in U2OS cells and $55 \%$ in HEK293 cells. Expression of Sp1 stimulated LRP5 promoter activity in a Sp1-binding site dependent manner. Therefore, Sp1 binding site located between -72 and -53 contributes to activation of the LRP5 promoter.

KLF15 can directly interact with MEF2, and activates the GLUT4 promoter in a synergetic manner[26]. Yamamoto et al demonstrated that KLF15 in combination with $\mathrm{Sp} 1$, synergistically activates the AceCS2 promoter [29]. In human LRP5 promoter, KLF15 and Sp1 motifs overlap. Simultaneously mutating KLF15 and Sp1 binding elements decreased the promoter activity more dramatically. This activation may be mediated by a synergetic interaction between the KLF15 and Sp1 factors resulting in a combined effect on the promoter activity.

\section{Conclusions}

Based on these data, we conclude that both KLF15 and Sp1 binding sites located between positions -72 to -53 relative to the transcription start site play critical roles in regulating the basal transcription of human LRP5 gene. The characterization of the human LRP5 basal promoter represents a starting point to further unravel the underlying molecular mechanisms that regulate human LRP5 expression, contributing to the understanding of how the function of LRP5 is regulated during bone formation and eye development.

\section{Methods}

\section{Cell culture}

Human osteosarcoma cells (U2OS) and human embryonic kidney cells (HEK293) were purchased from the American Type Culture Collection (Manassas, VA). U2OS Cells were cultured in McCoy's 5A medium 


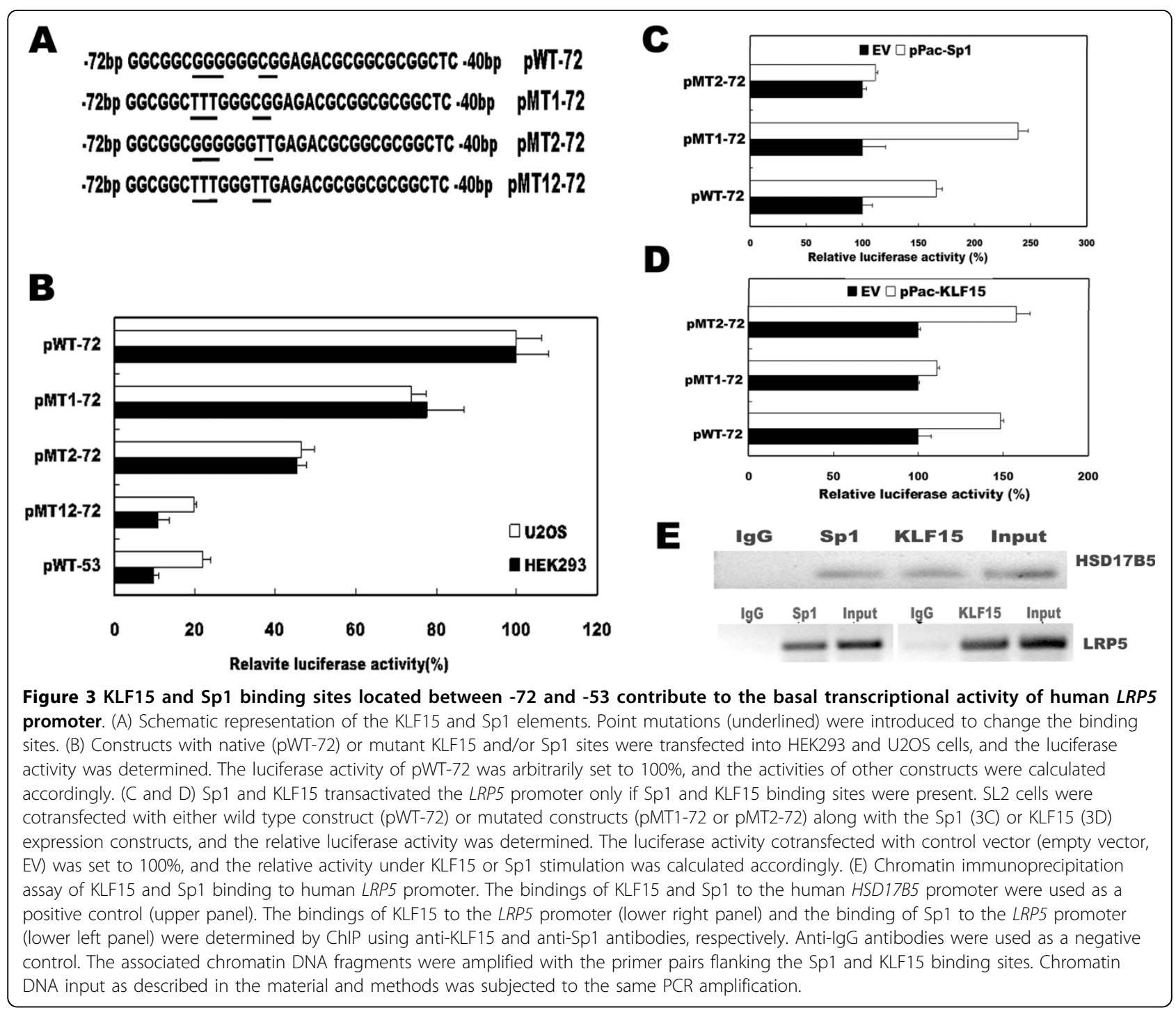

(Gibco, Invitrogen). HEK293 cells were maintained in Dulbecco's modified Eagle's medium (DMEM) (Gibco, Invitrogen). All media contained $10 \%$ fetal bovine serum (FBS), 100 units $/ \mathrm{ml}$ penicillin, and $100 \mathrm{mg} / \mathrm{ml}$ streptomycin (Gibco BRL). Cells were incubated in a humidified incubator equilibrated with $5 \% \mathrm{CO}_{2}$ at $37^{\circ} \mathrm{C}$. Drosophila melanogaster Schneider cell line 2 (SL2; ATCC No. CRL-1963) was purchased from Invitogen (Carlsbad, CA) and maintained in Schneider's insect medium supplemented with $10 \%$ fetal bovine serum and $2 \mathrm{mM}$ L-glutamine plus 100 units $/ \mathrm{ml}$ penicillin and 100 $\mathrm{mg} / \mathrm{ml}$ streptomycin, and cultured at $25^{\circ} \mathrm{C}$.

\section{RNA isolation and primer extension}

When reaching $80 \%$ confluence in $75 \mathrm{~cm}^{2}$ flasks, U2OS cells were washed twice with ice-cold PBS and total RNA was isolated with the use of TRIzol reagents (Sigma-Aldrich, St. Louis, USA) according to the manufacturer's protocol. Any potential DNA contamination was removed by RNase-free DNase treatment. The transcription start site of human LRP5 gene was determined by primer extension using a primer extension system (Promega). An antisense primer (5'GGCGGCGCTGCCTCCATGTTGTCCG-3'), corresponding to positions +107 to +131 (relative to transcription start site) of human LRP5 cDNA (GenBank accession No. NM_002335), was 5'end-labeled with $[\gamma$ $\left.-{ }^{32} \mathrm{P}\right]$ ATP $(3000 \mathrm{Ci} / \mathrm{mmol})$ using $\mathrm{T}_{4}$ polynucleotide kinase. The ${ }^{32} \mathrm{P}$-labeled primer of $10^{6} \mathrm{cpm}$ was added to $50 \mu \mathrm{g}$ of total RNA from U2OS cells in a final volume of $20 \mu \mathrm{l}$. The reverse transcription was performed with AMV reverse transcriptase according to the manufacturer's protocol. The reaction products were analyzed on $6 \%$ polyacrylamide/7 $\mathrm{M}$ urea gels alongside manual sequencing reaction of the plasmid DNA containing the 
5'-flanking region of human LRP5 gene with the same end-labeled primer.

\section{Plasmids and Constructs}

Utilizing the NCBI GenBank, we identified the genomic sequence of human LRP5 and found a BAC clone (PR11149G19) containing the human $L R P 5$ gene. We therefore amplified the proximal 5' region of human LRP5 (-2381 to +125 bp relative to transcription start site) by PCR using PR11-149G19 clone as the template. The primers (LRP5F and LRP5R) used are listed in Table 1. PCR product was cloned into pMD18-T vector (TaKaRa), and then subcloned into the firefly luciferase reporter vector pGL3-basic, a promoter-less luciferase expression plasmid (Promega, Madison, WI), creating pWT-2381. This construct was subsequently used as a template for the generation of a series of 5' unidirectional truncation mutants by PCR using assorted sense primers with a common antisense primer, LRP5R/HindIII (Table 1).

Mutant versions for specific binding sites were prepared by PCR-based mutagenesis from pWT-72, using the common reverse primer LRP5R/Hind III combining with the forward primers -72MT1/MluI, -72MT2/MluI and -72MT12/MluI, respectively (Table 1). The PCR conditions were as follows: the samples were denatured at $94^{\circ} \mathrm{C}$ for $4 \mathrm{~min}$, and then 30 cycles were applied: $94^{\circ} \mathrm{C}$ for $40 \mathrm{~s}, 60^{\circ} \mathrm{C}$ for $40 \mathrm{~s}$ and $72^{\circ} \mathrm{C}$ for $50 \mathrm{~s}$, the samples were further held at $72^{\circ} \mathrm{C}$ for $10 \mathrm{~min}$. PCR products were digested with KpnI (or MluI) and HindIII enzymes, gel-purified, and ligated to the pGL3-basic vector. The sequences of all constructs were confirmed by restriction enzyme digestion and direct sequencing.

pPac, a Drosophila actin 5C promoter-driven expression vector, pPac-gal containing an Escherichia coligalactosidase, and pPacSp1 containing Sp1, were provided by Dr. G. Suske (Philipps-Universität Marburg, Germany)[32]. The KLF15 coding cDNA was generated by reverse transcription-PCR from HEK293 total RNA with forward (5'-CGCGGATCCATGGTGGACCACTTACTTCCAGTGGACGAG-3') and reverse (5'CCGCTCGAGTCAGTTCACGGAGCGCACG-

GAGCGGCTGCTC-3') primers. BamHI and XhoI restriction sites, respectively (bold), were introduced into the primers for subcloning. The amplicons were digested with BamHI and XhoI and inserted into the Drosophila pPac expression vector after excision of the $\mathrm{Sp} 1$ coding sequence from $\mathrm{pPacSp} 1$. Construct sequences were confirmed by DNA sequencing.

\section{Transient transfection and luciferase assay}

Transient transfections were performed with the use of Lipofectamine 2000 reagent (Invitrogen) as previously described[33]. Briefly, U2OS and HEK293 cells were seeded into 48 -well plates at a density of $5 \times 10^{4}$ cells per well and $4 \times 10^{4}$ cells per well, respectively, the day before transfection. For each well of cells, $0.4 \mu \mathrm{g}$ of the LRP5 promoter constructs (deletion and sitedirected mutants) were co-transfected with $0.02 \mu \mathrm{g}$ of

Table 1 The oligonucleotide sequence of primers used in PCR

\begin{tabular}{|c|c|c|c|}
\hline Name & Sequence $\left(5^{\prime} \rightarrow 3^{\prime}\right)$ & Strand & Location \\
\hline LRP5F & GCCTGACTGAGGAGCTGAAG & sense & $-2381 \sim-2361$ \\
\hline LRP5R & GCTGCCTCCATGTTGTCC & antisense & $+105 \sim+125$ \\
\hline LRP5R/HindIII & CCCAAGCTTGCTGCCTCCATGTTGTCC & antisense & $+105 \sim+125$ \\
\hline$-1901 \mathrm{~F} / \mathrm{Kpnl}$ & GACGGTACCAGCTACGATCACACCACTAC & Sense & $-1901 \sim-1881$ \\
\hline$-1594 \mathrm{~F} / \mathrm{Kpnl}$ & GACGGTACCGGCTGCCATGAGATCAGGTG & Sense & $-1594 \sim-1574$ \\
\hline$-1442 \mathrm{~F} / \mathrm{Kpnl}$ & GACGGTACCAGGCTGTGCTGGTAGAGCTG & sense & $-1442 \sim-1422$ \\
\hline-1309 F/Kpnl & GACGGTACCCTGTACCTTCTACCACCAGC & Sense & $-1309 \sim-1279$ \\
\hline-1167 F/Kpnl & GACGGTACCITGGTAGCAGCTCAAGTGTC & Sense & $-1167 \sim-1147$ \\
\hline$-1085 \mathrm{~F} / \mathrm{Kpnl}$ & GACGGTACCTTCTTCATGGCCTGTCAATG & Sense & $-1085 \sim-1065$ \\
\hline-953 F/Kpnl & GACGGTACCAATCTGGAGGAACACACACG & Sense & $-953 \sim-933$ \\
\hline-359 F/Kpnl & GACGGTACCTGAAACTGCCTCGCTGTGTG & Sense & $-359 \sim-339$ \\
\hline-219 F/Kpnl & GACGGTACCGCCAAGCCTCCCGGAGGCAC & Sense & $-219 \sim-199$ \\
\hline-167 F/Kpnl & GACGGTACCCCGCGGGGACCTGCGCCGCT & Sense & $-167 \sim-147$ \\
\hline-72 F/Mlul & CGACGCGTGGCGGCGGGGGGCGGAGAAG & Sense & $-72 \sim-52$ \\
\hline-53 F/Mlul & CGACGCGTGCGGCGCGGCTTCCGCTCCCG & Sense & $-53 \sim-33$ \\
\hline$-40 \mathrm{~F} / \mathrm{Kpnl}$ & GACGGTACCCGCTCCCGCGCGCCCAGCTC & Sense & $-40 \sim-20$ \\
\hline$-72 \mathrm{MT1} / \mathrm{Mlul}$ & CGACGCGTGGCGGCTITGGGCGGAGAAG & Sense & $-72 \sim-52$ \\
\hline$-72 \mathrm{MT2} / \mathrm{Mlul}$ & CGACGCGTGGCGGCGGGGGGTTGAGAAGCGGCG & Sense & $-72 \sim-52$ \\
\hline$-72 \mathrm{MT} 12 / \mathrm{Mlul}$ & CGACGCGTGGCGGCTTGGGTTGAGAAGCGGCG & Sense & $-72 \sim-52$ \\
\hline
\end{tabular}

Location: Nucleotide positions relative to the transcription start site $(+1)$ of the human LRP5 gene.

Restriction sites are indicated in bold. The nucleotides of specific mutagenesis are indicated in italic and bold. 
pRL-TK plasmid (Promega). The cells were cultured for 24 hours after transfection and then harvested. Luciferase activity was measured using the Dual-Luciferase Reporter Assay System (Promega). To normalize for transfection efficiency, the promoter activity of each construct was expressed as the ratio of firefly luciferase activity to Renilla luciferase activity. For each construct, more than three independent experiments with U2OS and HEK293 cells were performed in triplicate.

For transient transfection of SL2 cells, one day prior to transfection, cells were plated into 24-well plates at a density of $5 \times 10^{5}$ cells/well. Cells were transfected with $0.5 \mu \mathrm{g}$ of indicated reporter construct (pWT-72, pMT172 and pMT2-72) and $0.1 \mu \mathrm{g}$ of pPacSp1 or pPac KLF15 expression vector or empty vector $\mathrm{pPac0}$ together with pPac- $\beta$-gal vector (internal reference encoding the $\beta$ galactosidase gene). Twenty-four hours after transfection, the cells were harvested and luciferase activity was measured using Bright-Glo luciferase assay system (Promega) and $\beta$-galactosidase activity was measured using Beta-Glo assay system (Promega). Luciferase activities were normalized to $\beta$-galactosidase activity, reported as means of three independent experiments, and each performed in duplication.

\section{Chromatin immunoprecipitation assays (ChIP)}

ChIP assays were performed using an EZ-ChIP assay kit (Upstate Biotechnologies, Millipore, MA) according to the manufacturer's instructions. Briefly, HEK293 cells were treated with formaldehyde and lysed with lysis buffer. The cell lysates were sonicated to generate 200-1000 bp DNA fragments, and cross-linked proteins were immunoprecipitated by incubation with antibodies against Sp1 (Santa Cruz, CA), KLF15 (Abcam, cambridge, UK), and IgG, respectively. A DNA sample from sonicated nuclear lysates that underwent reverse crosslink and phenol/chloroform extraction was used as positive control (input). A DNA sample immunoprecipitated by antibodies against IgG was used as negative control. Immunoprecipitated DNA was detected by PCR amplification using primer LRP5-ChIP-forward (5'CCGCGGGGACCTGCGCCGCT-3') combining with primer LRP5R. As a positive control, specific primers of HSD17B5 promoter (5'-TTCTCCACAGACCATATAAG-3' and 5'-TTCCCTGTCACTTGTCTGACT-3') were designed to amplify the promoter region containing Sp1 the KLF15 binding sites [22]. PCR products were separated on $2 \%$ agarose gel and visualized by ethidium bromide staining.

\section{Statistical analysis}

The statistical significance of differences between experimental groups was calculated using the Student's test.
Group differences were considered significant if $\mathrm{P}<$ 0.05 .

\section{List of abbreviations}

LRP5: low-density lipoprotein receptor related protein; Sp1: specificity protein 1; KLF15: Krüppel-like factor 15; ChIP: chromatin immunoprecipitation; HSD17B5: human 17-hydroxysteroid dehydrogenase type 5 gene.

\section{Acknowledgements}

We thank Dr. G. Suske, Philipps-Universität Marburg, Germany, for kindly providing pPac-gal and pPacSp1 constructs. We also express our thanks to Dr. Changshun Shao for critical reading of the manuscript and helpful advice. This work was supported by National Basic Research Program of China; grant number 2007CB512001, and National High-tech Research and Development Program of China; grant number: 2006AA02A406.

\section{Authors' contributions}

\lrcorner performed luciferase reporter assay and ChIP analysis, and drafted the manuscript. $Y Y$ and BJ participated in the primer extension and reporter assays. $X Z$ and $Y Z$ assisted in RNA isolation and vector construction. YG contributed to the conception and the design of the study and the writing of the manuscript. All authors read and approved the final manuscript.

Received: 13 October 2009

Accepted: 8 February 2010 Published: 8 February 2010

\section{References}

1. Hey PJ, Twells RC, Phillips MS, Yusuke N, Brown SD, Kawaguchi Y, Cox R, Guochun X, Dugan V, Hammond H, Metzker ML, Todd JA, Hess JF: Cloning of a novel member of the low-density lipoprotein receptor family. Gene 1998, 216:103-111.

2. Wehrli M, Dougan ST, Caldwell K, O'Keefe L, Schwartz S, Vaizel-Ohayon D, Schejter E, Tomlinson A, DiNardo S: Arrow encodes an LDL-receptorrelated protein essential for Wingless signalling. Nature 2000, 407:527-530.

3. Tamai K, Semenov M, Kato Y, Spokony R, Liu C, Katsuyama Y, Hess F, SaintJeannet JP, He X: LDL-receptor-related proteins in Wnt signal transduction. Nature 2000, 407:530-535.

4. Gong Y, Slee RB, Fukai N, Rawadi G, Roman-Roman S, Reginato AM, Wang $H$, Cundy $T$, Glorieux FH, Lev D, Zacharin M, Oexle K, Marcelino J, Suwairi W, Heeger S, Sabatakos G, Apte S, Adkins WN, Allgrove J, ArslanKirchner M, Batch JA, Beighton P, Black GC, Boles RG, Boon LM, Borrone C, Brunner HG, Carle GF, Dallapiccola B, De Paepe A, Floege B, Halfhide ML, Hall B, Hennekam RC, Hirose T, Jans A, Juppner H, Kim CA, KepplerNoreuil K, Kohlschuetter A, LaCombe D, Lambert M, Lemyre E, Letteboer T, Peltonen L, Ramesar RS, Romanengo M, Somer $H$, Steichen-Gersdorf E, Steinmann B, Sullivan B, Superti-Furga A, Swoboda W, Boogaard van den MJ, Van Hul W, Vikkula M, Votruba M, Zabel B, Garcia T, Baron R, Olsen BR, Warman ML: LDL receptor-related protein 5 (LRP5) affects bone accrual and eye development. Cell 2001, 107:513-523.

5. Kato M, Patel MS, Levasseur R, Lobov I, Chang BH, Glass DA, Hartmann C, Li L, Hwang TH, Brayton CF, Lang RA, Karsenty G, Chan L: Cbfa1independent decrease in osteoblast proliferation, osteopenia, and persistent embryonic eye vascularization in mice deficient in Lrp5, a Wnt coreceptor. J Cell Biol 2002, 157:303-314.

6. Boyden LM, Mao J, Belsky J, Mitzner L, Farhi A, Mitnick MA, Wu D, Insogna K, Lifton RP: High bone density due to a mutation in LDLreceptor-related protein 5. N Engl J Med 2002, 346:1513-1521.

7. Little RD, Carulli JP, Del Mastro RG, Dupuis J, Osborne M, Folz C, Manning SP, Swain PM, Zhao SC, Eustace B, Lappe MM, Spitzer L, Zweier S, Braunschweiger K, Benchekroun Y, Hu X, Adair R, Chee L, FitzGerald MG, Tulig C, Caruso A, Tzellas N, Bawa A, Franklin B, McGuire S, Nogues X, Gong G, Allen KM, Anisowicz A, Morales AJ, Lomedico PT, Recker SM, Van Eerdewegh $P$, Recker RR, Johnson ML: A mutation in the LDL receptorrelated protein 5 gene results in the autosomal dominant high-bonemass trait. Am J Hum Genet 2002, 70:11-19. 
8. Van Wesenbeeck L, Cleiren E, Gram J, Beals RK, Benichou O, Scopelliti D, Key L, Renton T, Bartels C, Gong Y, Warman ML, De Vernejoul MC, Bollerslev J, Van Hul W: Six novel missense mutations in the LDL receptor-related protein 5 (LRP5) gene in different conditions with an increased bone density. Am J Hum Genet 2003, 72:763-771.

9. Babij P, Zhao W, Small C, Kharode Y, Yaworsky PJ, Bouxsein ML, Reddy PS, Bodine PV, Robinson JA, Bhat B, Marzolf J, Moran RA, Bex F: High bone mass in mice expressing a mutant LRP5 gene. J Bone Miner Res 2003, 18:960-974.

10. Urano T, Shiraki M, Ezura Y, Fujita M, Sekine E, Hoshino S, Hosoi T, Orimo H, Emi M, Ouchi $Y$, Inoue S: Association of a single-nucleotide polymorphism in low-density lipoprotein receptor-related protein 5 gene with bone mineral density. J Bone Miner Metab 2004, 22:341-345.

11. Ferrari SL, Deutsch S, Antonarakis SE: Pathogenic mutations and polymorphisms in the lipoprotein receptor-related protein 5 reveal a new biological pathway for the control of bone mass. Curr Opin Lipidol 2005, 16:207-214.

12. Koller DL, Ichikawa S, Johnson ML, Lai D, Xuei X, Edenberg HJ, Conneally PM, Hui SL, Johnston CC, Peacock M, Foroud T, Econs MJ: Contribution of the LRP5 gene to normal variation in peak BMD in women. J Bone Miner Res 2005, 20:75-80.

13. Kiel DP, Ferrari SL, Cupples LA, Karasik D, Manen D, Imamovic A, Herbert AG, Dupuis J: Genetic variation at the low-density lipoprotein receptor-related protein 5 (LRP5) locus modulates Wnt signaling and the relationship of physical activity with bone mineral density in men. Bone 2007, 40:587-596.

14. Jiao X, Ventruto V, Trese MT, Shastry BS, Hejtmancik JF: Autosomal recessive familial exudative vitreoretinopathy is associated with mutations in LRP5. Am J Hum Genet 2004, 75:878-884.

15. Qin M, Hayashi H, Oshima K, Tahira T, Hayashi K, Kondo H: Complexity of the genotype-phenotype correlation in familial exudative vitreoretinopathy with mutations in the LRP5 and/or FZD4 genes. Hum Mutat 2005, 26:104-112.

16. Toomes C, Bottomley HM, Jackson RM, Towns KV, Scott S, Mackey DA, Craig JE, Jiang L, Yang Z, Trembath R, Woodruff G, Gregory-Evans CY, Gregory-Evans K, Parker MJ, Black GC, Downey LM, Zhang K, Inglehearn CF: Mutations in LRP5 or FZD4 underlie the common familial exudative vitreoretinopathy locus on chromosome 11q. Am J Hum Genet 2004, 74:721-730.

17. Xu Q, Wang Y, Dabdoub A, Smallwood PM, Williams J, Woods C, Kelley MW, Jiang L, Tasman W, Zhang K, Nathans J: Vascular development in the retina and inner ear: control by Norrin and Frizzled-4, a highaffinity ligand-receptor pair. Cell 2004, 116:883-895

18. Haines JL, Schnetz-Boutaud N, Schmidt S, Scott WK, Agarwal A, Postel EA, Olson L, Kenealy SJ, Hauser M, Gilbert JR, Pericak-Vance MA: Functional candidate genes in age-related macular degeneration: significant association with VEGF, VLDLR, and LRP6. Invest Ophthalmol Vis Sci 2006, 47:329-335.

19. Fujino T, Asaba H, Kang MJ, Ikeda Y, Sone H, Takada S, Kim DH, loka RX, Ono M, Tomoyori H, Okubo M, Murase T, Kamataki A, Yamamoto J, Magoori K, Takahashi S, Miyamoto Y, Oishi H, Nose M, Okazaki M, Usui S, Imaizumi K, Yanagisawa M, Sakai J, Yamamoto TT: Low-density lipoprotein receptor-related protein 5 (LRP5) is essential for normal cholesterol metabolism and glucose-induced insulin secretion. Proc Natl Acad Sci USA 2003, 100:229-234.

20. Magoori K, Kang MJ, Ito MR, Kakuuchi H, loka RX, Kamataki A, Kim DH, Asaba H, Iwasaki S, Takei YA, Sasaki M, Usui S, Okazaki M, Takahashi S, Ono M, Nose M, Sakai J, Fujino T, Yamamoto T: Severe hypercholesterolemia, impaired fat tolerance, and advanced atherosclerosis in mice lacking both low density lipoprotein receptorrelated protein 5 and apolipoprotein E. J Biol Chem 2003, 278:11331-11336.

21. Yadav VK, Ryu JH, Suda N, Tanaka KF, Gingrich JA, Schutz G, Glorieux FH, Chiang CY, Zajac JD, Insogna KL, Mann JJ, Hen R, Ducy P, Karsenty G: Lrp5 controls bone formation by inhibiting serotonin synthesis in the duodenum. Cell 2008, 135:825-837.

22. Du X, Rosenfield RL, Qin K: KLF15 Is a transcriptional regulator of the human 17beta-hydroxysteroid dehydrogenase type 5 gene. A potential link between regulation of testosterone production and fat stores in women. J Clin Endocrinol Metab 2009, 94:2594-2601.
23. Bieker JJ: Kruppel-like factors: three fingers in many pies. $J$ Biol Chem 2001, 276:34355-34358.

24. Kaczynski J, Cook T, Urrutia R: Sp1- and Kruppel-like transcription factors. Genome Biol 2003, 4:206.

25. Cook T, Gebelein B, Belal M, Mesa K, Urrutia R: Three conserved transcriptional repressor domains are a defining feature of the TIEG subfamily of Sp1-like zinc finger proteins. J Biol Chem 1999, 274:29500-29504.

26. Gray S, Feinberg MW, Hull S, Kuo CT, Watanabe M, Sen-Banerjee $S$, DePina A, Haspel R, Jain MK: The Kruppel-like factor KLF15 regulates the insulin-sensitive glucose transporter GLUT4. J Biol Chem 2002, 277:34322-34328.

27. Otteson DC, Liu Y, Lai H, Wang C, Gray S, Jain MK, Zack DJ: Kruppel-like factor 15, a zinc-finger transcriptional regulator, represses the rhodopsin and interphotoreceptor retinoid-binding protein promoters. Invest Ophthalmol Vis Sci 2004, 45:2522-2530.

28. Uchida S, Tanaka Y, Ito H, Saitoh-Ohara F, Inazawa J, Yokoyama KK, Sasaki S, Marumo F: Transcriptional regulation of the CLC-K1 promoter by mycassociated zinc finger protein and kidney-enriched Kruppel-like factor, a novel zinc finger repressor. Mol Cell Biol 2000, 20:7319-7331.

29. Yamamoto J, Ikeda Y, Iguchi H, Fujino T, Tanaka T, Asaba H, Iwasaki S, loka RX, Kaneko IW, Magoori K, Takahashi S, Mori T, Sakaue H, Kodama T, Yanagisawa M, Yamamoto TT, Ito S, Sakai J: A Kruppel-like factor KLF15 contributes fasting-induced transcriptional activation of mitochondrial acetyl-CoA synthetase gene AceCS2. J Biol Chem 2004, 279:16954-16962.

30. Suske G: The Sp-family of transcription factors. Gene 1999, 238:291-300.

31. Philipsen S, Suske G: A tale of three fingers: the family of mammalian Sp/ XKLF transcription factors. Nucleic Acids Res 1999, 27:2991-3000.

32. Hagen G, Muller S, Beato M, Suske G: Sp1-mediated transcriptional activation is repressed by Sp3. Embo J 1994, 13:3843-3851.

33. Xia Y, Jiang B, Zou Y, Gao G, Shang L, Chen B, Liu Q, Gong Y: Sp1 and CREB regulate basal transcription of the human SNF2L gene. Biochem Biophys Res Commun 2008, 368:438-444.

doi:10.1186/1471-2156-11-12

Cite this article as: Li et al:: Sp1 and KLF15 regulate basal transcription of the human LRP5 gene. BMC Genetics 2010 11:12.

\section{Submit your next manuscript to BioMed Central and take full advantage of:}

- Convenient online submission

- Thorough peer review

- No space constraints or color figure charges

- Immediate publication on acceptance

- Inclusion in PubMed, CAS, Scopus and Google Scholar

- Research which is freely available for redistribution

Submit your manuscript at www.biomedcentral.com/submit
C Biomed Central 